\title{
Postural changes versus balance control and falls in community-living older adults: a systematic review
}

\author{
Alterações posturais versus controle do equilíbrio e quedas \\ em idosos da comunidade: Revisão sistemática
}

\author{
Viviane Lemos Silva Fernandes ${ }^{[a, b]}$, Darlan Martins Ribeiro ${ }^{[a, c]}$, Luciana Caetano Fernandes ${ }^{[a, c]}$, \\ Ruth Losada de Menezes ${ }^{[\mathrm{a}]^{*}}$
}

[a] Universidade de Brasília (UnB), Brasília, DF, Brazil

[b] Centro Universitário de Anápolis (UniEVANGELICA), Anápolis, GO, Brazil

[c] Universidade Estadual de Goiás (UEG), Goiânia, GO, Brazil

\begin{abstract}
Introduction: Since falls are considered to be a public health problem, it is important to identify whether postural changes over time contribute to the risk of falls in older adults. Objective: To investigate whether postural changes increase fall risk and/or postural imbalance in healthy, community-dwelling older adults. Methods: In April 2016, two reviewers independently searched the PubMed, Web of Science, SPORTDiscus, and CINAHL databases for studies in English published in the previous 10 years, using the following combined keywords: "posture” or ("kyphosis","lumbar lordosis","flexed posture”,"spinal curvature","spinal sagittal contour") AND "elderly" AND "fall". Study quality was assessed according to the STROBE (Strengthening the Reporting of Observational Studies in Epidemiology) guidelines for observational studies. Results: The search retrieved 1,734 articles. Only observational studies that assessed posture, balance, and/or falls in older adults were considered eligible for review. The final sample included 17 articles: reliability and reproducibility of the instruments were not reported in five studies, while two studies offered a questionable description of the instruments used. Fourteen
\end{abstract}

\footnotetext{
VLSF: Doctoral student, e-mail: vivi4fernandes@gmail.com DMR: Master's student, e-mail: darlan.ribeiro@hotmail.com LCF: Doctoral student, e-mail: lucaetanofernnades@gmail.com RLM: PhD, e-mail: ruthlosada@unb.br
} 
articles analyzed postural changes at the trunk level and three articles assessed them at the ankles and feet. Most studies found a positive association between postural changes and an increased risk for loss of balance and falls. Conclusion: Thoracic hyperkyphosis, loss of lumbar lordosis, and decreased plantar arch seem to contribute to greater postural instability, and thus to a higher risk of falls in community-living older adults.

Keywords: Older Adults. Posture. Postural Balance. Accidental Falls.

\section{Resumo}

Introdução: As quedas são consideradas um problema de saúde pública, portanto torna-se relevante identificar se as alterações que a postura sofre no decorrer dos anos contribui para o risco de quedas em idosos. Objetivo: Analisar se as alterações posturais favorecem as quedas e/ou desequilíbrio postural, em idosos saudáveis da comunidade. Métodos: A busca ocorreu no mês de abril de 2016, de forma independente, por dois revisores, nas bases de dados PubMed, Web of Science, SPORTDiscus, e CINAHL, com delimitação de publicação dos últimos 10 anos, em língua inglesa, com as palavras chaves "posture" ou ("kyphosis","lumbar lordose","flexed posture","spinal curvature","spinal sagital contour") em combinação com "elderly" e "fall". A qualidade dos estudos foi avaliada pelas diretrizes do STROBE (Strengthening the Reporting of Observational Studies in Epidemiology) para estudos observacionais. Resultados: Foram encontrados 1734 artigos, sendo considerados elegíveis, os estudos observacionais com avaliação postural, equilíbrio e/ou quedas em idosos, em um total de 17 artigos analisados. A confiabilidade e reprodutibilidade dos instrumentos não foram informados em cinco estudos, e em dois apresentaram descriçao questionável. Quatorze artigos analisaram alterações posturais a nível de tronco e 03 artigos avaliaram tornozelos e pés. A maioria dos estudos encontraram associaçao entre as alterações posturais com a perda do equilibrio e aumento das quedas em idosos. Conclusão: Hipercifose torácica, retificação da lordose lombar, diminuição do arco plantar de idosos que vivem na comunidade, parecem contribuir para maior instabilidade postural, e consequentemente aumentar o risco de quedas na população idosa que vive na comunidade.

Palavras-chave: Idoso. Postura. Equilíbrio Postural. Acidentes por Quedas.

\section{Introduction}

Falls are considered to be an important public health problem due to the risks of morbidity and mortality [1]. In Brazil, about $30 \%$ of community-living older adults report falling at least once a year [2 - 4].

In addition to environmental risks [5], the literature points out several risk factors intrinsic to falls, such as age, female gender, functional disability, balance deficit, gait disorders, sedentary lifestyle, poor health self-perception, use of psychotropic drugs, muscle weakness, reduced visual acuity, cognitive deficits, and polypharmacy [1 - 7].

Although posture is not considered a risk factor for falls, several studies investigated the relationship between posture and body balance and/or falls in older adults [8 - 12]. The Guide to
Physical Therapist Practice of the American Physical Therapy Association (APTA) defines posture as "the alignment and positioning of the body in relation to gravity, center of mass, or base of support" [13]. In ideal posture, there is a state of muscular and skeletal equilibrium and an adequate tension on support structures for a more efficient balance control [13].

Ideal postural alignment is indirectly associated with aging $[8,12,14]$. The body undergoes changes in the bones, muscles, and joints that lead to changes in the physiological spinal curvature [10, 13]. Thoracic hyperkyphosis is the most common, affecting $20-40 \%$ of older adults worldwide [15], along with osteoporosis as an associated clinical condition [16]. Patients with hyperkyphosis may have anterior displacement of the head, protrusion 
of the scapula, loss of lumbar lordosis [17], and, consequently, anteriorly project into the line of the center of gravity [8]. Changes in the projection of the center of gravity negatively affect body balance control [17].

The relationship between body balance and postural changes in the vertebral column due to the clinical condition of osteoporosis was also highlighted in the reviews by Hsu et al. [17] and Groot et al. [18]. These authors found poor balance control in patients with vertebral fractures, thoracic hyperkyphosis, and flexed posture.

A gap exists in the literature for systematic reviews to investigate how changes in postural alignment of different body segments affect postural stability and the risk of falls in healthy older adults. Thus, this study aimed to investigate whether postural changes increase fall risk and/or postural imbalance in healthy, community-dwelling older adults.

\section{Methods}

\section{Search Strategy}

In April 2016, two reviewers independently searched PubMed, Web of Science, SPORTDiscus, and CINAHL for studies in the last 10 years. After screening titles, abstracts and keywords, fulltext versions of potential papers were selected. Discrepancies were resolved by a third reviewer. The following keywords (DESCs and MESH terms) and search strings were used: (posture OR kyphosis OR lumbar lordosis OR flexed posture OR spinal curvature OR spinal sagittal contour AND elderly AND fall).

\section{Selection/Inclusion Criteria}

The inclusion criteria were English written observational studies assessing posture, balance, and/or falls in adults 60 years and older. We excluded duplicates, reviews, case studies, theses and dissertations, studies with special populations such as those with a specific pathology (for instance, Parkinson's disease, stroke, osteoporosis, etc.), and articles not available in full text.
Quality assessment

Study quality was assessed according to the STROBE (Strengthening the Reporting of Observational Studies in Epidemiology) guidelines for observational studies (Table 1) [19].

Table 1 - The STROBE checklist for assessment of methodological quality of observational studies

\begin{tabular}{|c|c|c|}
\hline ITEM & \multicolumn{2}{|c|}{ ASSESSMENT } \\
\hline & \multicolumn{2}{|c|}{ Introduction and methods } \\
\hline \multirow[t]{3}{*}{ 1. Study objective } & + & Clearly stated the study objective; \\
\hline & $?$ & Questionable description; \\
\hline & 0 & $\begin{array}{l}\text { Gave no information on the study } \\
\text { objectives. }\end{array}$ \\
\hline \multirow[t]{4}{*}{ 2. Setting/location } & + & $\begin{array}{l}\text { Described the setting, locations, } \\
\text { and relevant dates, including } \\
\text { periods of recruitment and } \\
\text { assessment, follow-up, and data } \\
\text { collection; }\end{array}$ \\
\hline & $?$ & Questionable description; \\
\hline & & $\begin{array}{l}\text { Only described the locations or the } \\
\text { dates (e.g., periods of recruitment, } \\
\text { assessment and follow-up); }\end{array}$ \\
\hline & 0 & $\begin{array}{l}\text { Gave no information on the } \\
\text { locations or relevant dates, } \\
\text { including periods of recruitment, } \\
\text { exposure, follow-up, and data } \\
\text { collection. }\end{array}$ \\
\hline \multirow[t]{4}{*}{ 3. Sample } & + & $\begin{array}{l}\text { Described the eligibility criteria, } \\
\text { the origin and the sources } \\
\text { and methods of selection of } \\
\text { participants; }\end{array}$ \\
\hline & $?$ & $\begin{array}{l}\text { Description of the eligibility criteria, } \\
\text { origin, and sources and methods } \\
\text { of selection of participants; }\end{array}$ \\
\hline & & $\begin{array}{l}\text { Only described the eligibility } \\
\text { criteria or the origin and the } \\
\text { sources and methods of selection } \\
\text { of participants; }\end{array}$ \\
\hline & + & $\begin{array}{l}\text { Gave no information on the } \\
\text { eligibility criteria, origin and } \\
\text { sources and methods of selection } \\
\text { of participants. }\end{array}$ \\
\hline \multirow[t]{3}{*}{ 4. Sample size } & + & Sample size calculation reported; \\
\hline & $?$ & $\begin{array}{l}\text { Questionable description of } \\
\text { sample size calculation; }\end{array}$ \\
\hline & 0 & $\begin{array}{l}\text { Gave no information on sample } \\
\text { size calculation. }\end{array}$ \\
\hline
\end{tabular}

(To be continued) 
Table 1 - The STROBE checklist for assessment of methodological quality of observational studies

\begin{tabular}{|c|c|c|}
\hline ITEM & AS & ESSMENT \\
\hline \multirow[t]{3}{*}{$\begin{array}{l}\text { 5. Control group } \\
\text { (if applicable) }\end{array}$} & + & $\begin{array}{l}\text { Properly explained how matching } \\
\text { of cases and controls was } \\
\text { addressed; }\end{array}$ \\
\hline & $?$ & $\begin{array}{l}\text { Questionable explanation of how } \\
\text { matching of cases ans controls } \\
\text { was addressed; }\end{array}$ \\
\hline & 0 & $\begin{array}{l}\text { Gave no information on how } \\
\text { matching of cases and controls } \\
\text { was addressed. }\end{array}$ \\
\hline \multirow[t]{3}{*}{ 6. Outcomes } & + & $\begin{array}{l}\text { All of the study outcomes were } \\
\text { clearly described; }\end{array}$ \\
\hline & $?$ & Questionable description; \\
\hline & 0 & $\begin{array}{l}\text { Gave no information on the study } \\
\text { outcomes assessed. }\end{array}$ \\
\hline \multirow[t]{3}{*}{ 7. Assessment } & + & $\begin{array}{l}\text { The methods used in the } \\
\text { assessment were described in the } \\
\text { paper; }\end{array}$ \\
\hline & $?$ & Questionable description; \\
\hline & 0 & $\begin{array}{l}\text { Gave no information on the } \\
\text { methods used in the assessment. }\end{array}$ \\
\hline \multirow[t]{3}{*}{$\begin{array}{l}\text { 8. Reliability and } \\
\text { reproducibility of } \\
\text { the tool used for } \\
\text { assessment }\end{array}$} & + & $\begin{array}{l}\text { The tool used for assessment } \\
\text { has intra- and inter-observer } \\
\text { reliability and reproducibility or the } \\
\text { intraclass correlation coefficient } \\
\text { was calculated for the outcome; }\end{array}$ \\
\hline & $?$ & Questionable description; \\
\hline & 0 & $\begin{array}{l}\text { Gave no information on intra- } \\
\text { and inter-observer reliability and } \\
\text { reproducibility. }\end{array}$ \\
\hline \multirow[t]{3}{*}{ 9. Bias } & + & $\begin{array}{l}\text { Described all efforts taken to } \\
\text { address potential sources of bias; }\end{array}$ \\
\hline & & $\begin{array}{l}\text { Did not describe any efforts taken } \\
\text { to address potential sources of } \\
\text { bias; }\end{array}$ \\
\hline & + & $\begin{array}{l}\text { Gave no information on any efforts } \\
\text { taken to address potential sources } \\
\text { of bias. }\end{array}$ \\
\hline \multirow{3}{*}{$\begin{array}{l}\text { 10. Statistical } \\
\text { methods }\end{array}$} & + & Described all statistical methods; \\
\hline & $?$ & $\begin{array}{l}\text { Questionable description of } \\
\text { statistical methods; }\end{array}$ \\
\hline & 0 & $\begin{array}{l}\text { Gave no information on statistical } \\
\text { methods. }\end{array}$ \\
\hline
\end{tabular}

(To be continued)
Table 1 - The STROBE checklist for assessment of methodological quality of observational studies

\begin{tabular}{|c|c|c|}
\hline \multirow[t]{2}{*}{ ITEM } & \multicolumn{2}{|c|}{ ASSESSMENT } \\
\hline & \multicolumn{2}{|c|}{ Results and discussion / conclusion } \\
\hline \multirow[t]{4}{*}{ 11. Participants } & + & $\begin{array}{l}\text { Reported the numbers of } \\
\text { individuals at each stage of the } \\
\text { study (e.g., numbers potentially } \\
\text { eligible, examined for eligibility, } \\
\text { confirmed eligible, included in the } \\
\text { study, completing follow-up, and } \\
\text { analyzed); }\end{array}$ \\
\hline & $?$ & Questionable description; \\
\hline & & $\begin{array}{l}\text { Did not describe the number of } \\
\text { individuals at each stage of the } \\
\text { study; }\end{array}$ \\
\hline & 0 & $\begin{array}{l}\text { Gave no information on the } \\
\text { number of participants. }\end{array}$ \\
\hline \multirow[t]{3}{*}{ 12. Descriptive data } & + & $\begin{array}{l}\text { Described the characteristics } \\
\text { of study participants (e.g., } \\
\text { demographic, clinical, social); }\end{array}$ \\
\hline & & $\begin{array}{l}\text { Did not describe all the } \\
\text { characteristics of study } \\
\text { participants; }\end{array}$ \\
\hline & 0 & $\begin{array}{l}\text { Gave no information on the } \\
\text { characteristics of study } \\
\text { participants. }\end{array}$ \\
\hline \multirow[t]{2}{*}{ 13. Results } & & $\begin{array}{l}\text { Clear description of study } \\
\text { outcomes; }\end{array}$ \\
\hline & $?$ & Questionable description. \\
\hline \multirow[t]{3}{*}{$\begin{array}{l}\text { 14. Clinical } \\
\text { implications }\end{array}$} & & $\begin{array}{l}\text { Clinical descriptions were } \\
\text { described according to study } \\
\text { outcomes; }\end{array}$ \\
\hline & $?$ & $\begin{array}{l}\text { Questionable description of clinical } \\
\text { implications; }\end{array}$ \\
\hline & 0 & $\begin{array}{l}\text { Gave no information on the } \\
\text { clinical implications of the study } \\
\text { outcomes. }\end{array}$ \\
\hline \multirow[t]{3}{*}{ 15. Limitations } & & $\begin{array}{l}\text { Discussed the limitations of the } \\
\text { study; }\end{array}$ \\
\hline & $?$ & $\begin{array}{l}\text { Questionable description of the } \\
\text { limitations of the study; }\end{array}$ \\
\hline & 0 & $\begin{array}{l}\text { Gave no information on the } \\
\text { limitations of the study. }\end{array}$ \\
\hline
\end{tabular}

Note: + = positive rating; ? = questionable study design or methodology; - = negative rating; 0 = information unavailable; $\mathrm{NA}=$ not applicable. 


\section{Results}

Characteristics of the studies retrieved

Figure 1 shows a flowchart describing the results of each step in the selection procedure. Of 1,734 articles retrieved, 17 were eligible for inclusion.

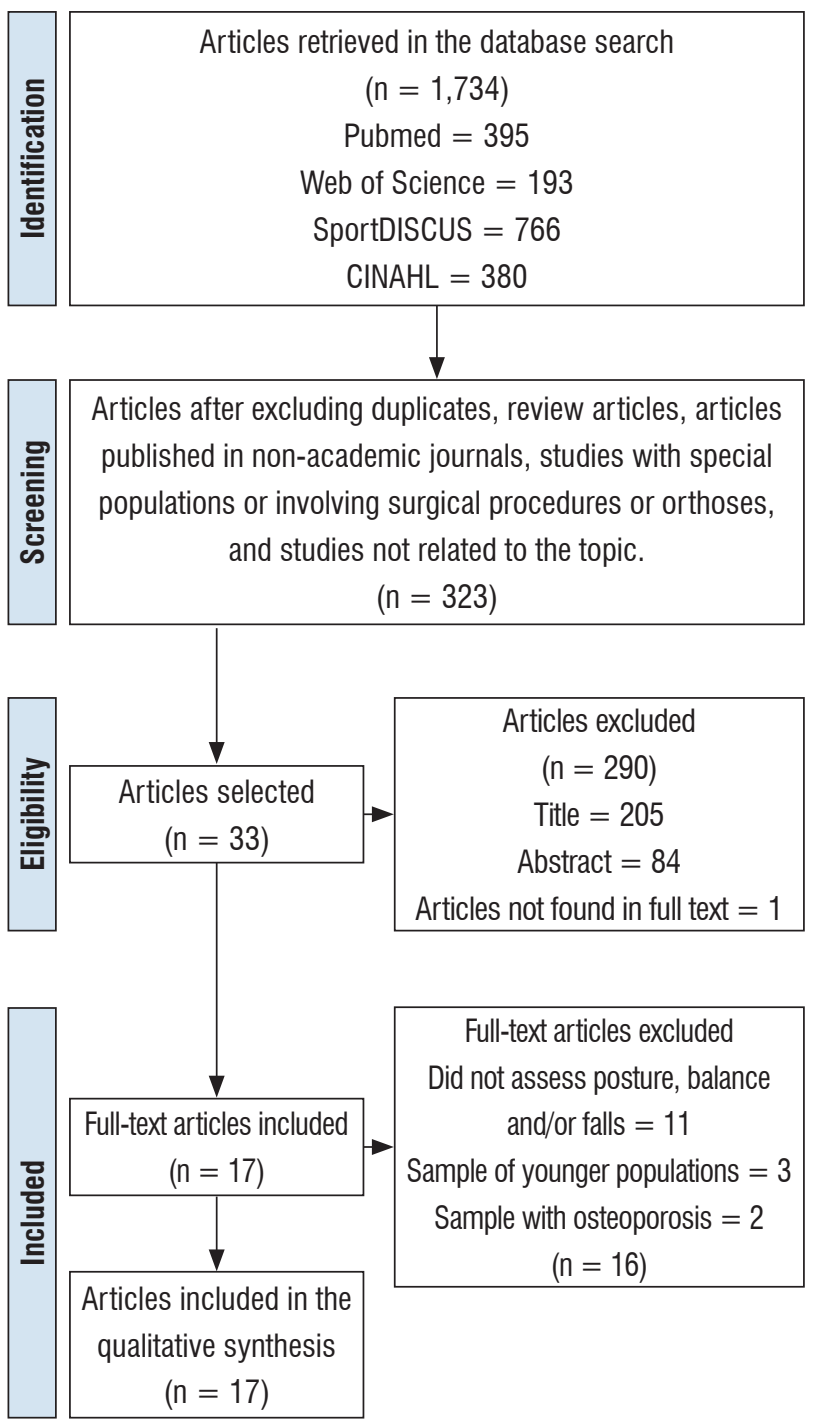

Figure 1 - Flowchart of the selection process using the PRISMA criteria [20].

Fifty per cent of the studies included in this review were conducted in Japan, while the remaining studies were representative of different geographical locations (Australia, USA, Netherlands, Italy, Japan, Malaysia, Poland).

The articles were analyzed with regard to design, sample characteristics, tools used to assess body posture, balance and/or falls risk, and outcomes (Table 2). Three studies have specifically assessed the feet and the ankles and their data are shown separately in Table 3.

Ten studies (58.8\%) were cross-sectional studies, five $(29.4 \%)$ were cohort studies (two of which were also prospective), one (5.9\%) was longitudinal, and one (5.9\%) was not defined (Tables 1 and 2). The following methods and tools were used to assess body posture: SpinalMouse [8, 21 - 24], occiput-to-wall distance (OWD) [25 - 27], method using $1.7 \mathrm{~cm}$ blocks [28], flexicurve ruler [29, 30], Cobb angle [24, 26, 27], photogrammetry/Moiré method [31], method with photographic recording [32] and digital inclinometer [33]. Foot posture was assessed using the Foot Posture Index (FPI) [34, 35], which tests foot characteristics across six domains: foot posture, foot deformity and lesions, plantar tactile sensation, toe muscle strength and foot pain, and a three-dimensional foot scanner (Footstep PRO, Dream GP Company, Japan) [36].

Falls were ascertained by the administration of a questionnaire, and assessed using the Falls Efficacy Scale (FES) [30]. Participants' falls risk was assessed using Pluijm's assessment [26] and the Physiological Profile Assessment (PPA) [34]. While most studies followed participants for 12 months $[10,21,24,28,34]$, in one study participants were followed for only six months [27].

Body balance was assessed using more accurate methods of measurement, such as stabilometry, force plate $[14,21,22,24,29,36]$, and functional tests such as the Timed Up and Go (TUG) test [8, 23, 32 - 35], functional reach (FR) [8], Berg Balance Scale (BBS) [30], one-led stance [23, 32, 33], Four-Square Step Test (FSST) $[34,35]$ and feet-together stance, semitandem and tandem standing [25]. 


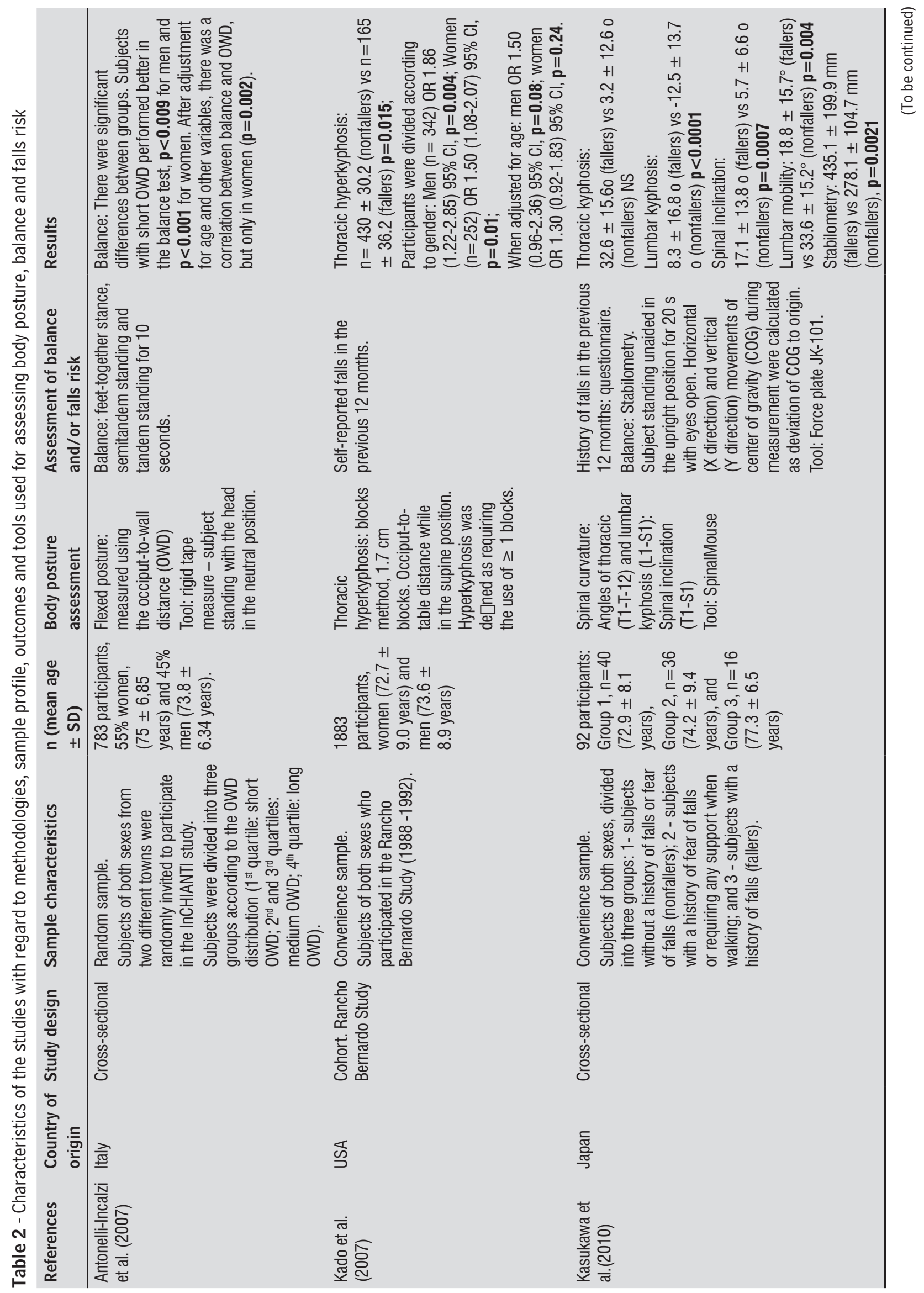




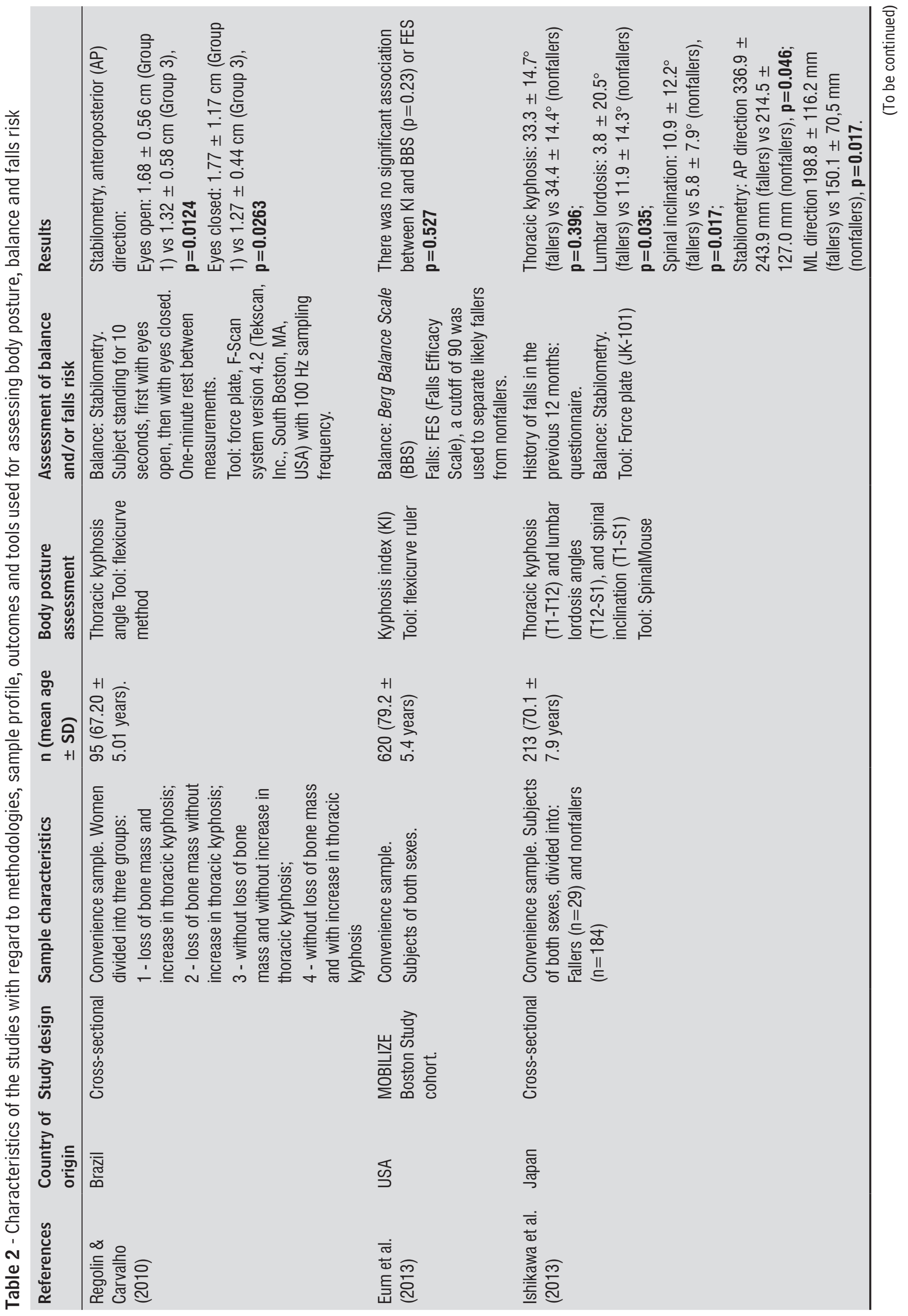




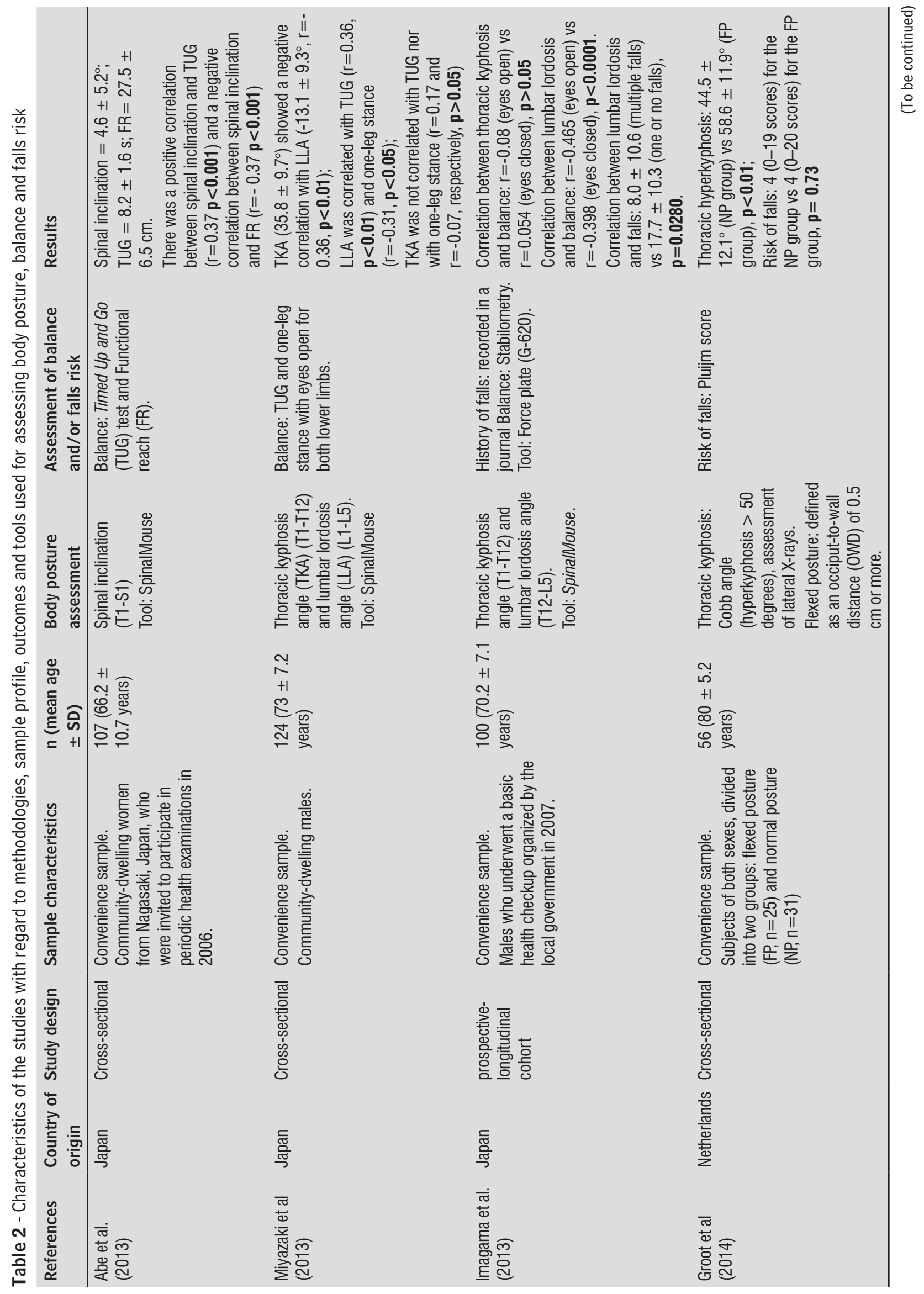




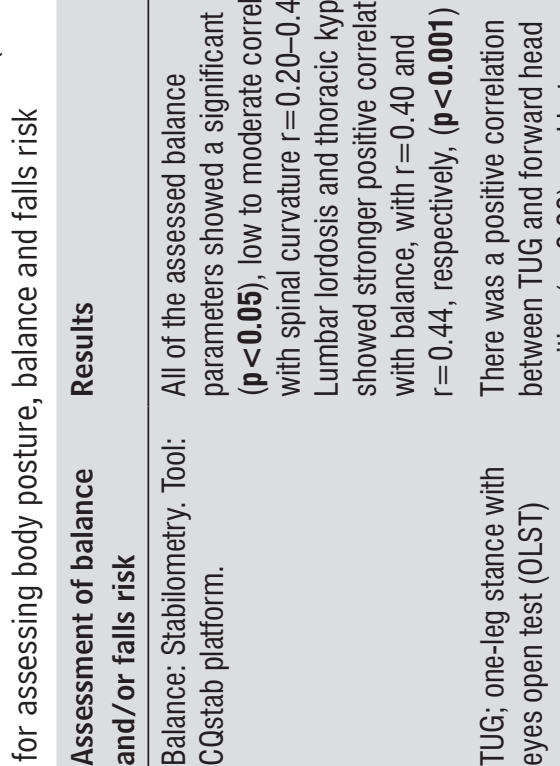

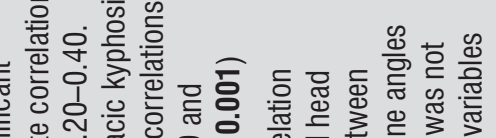

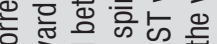

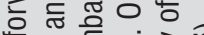

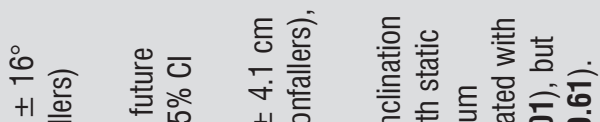

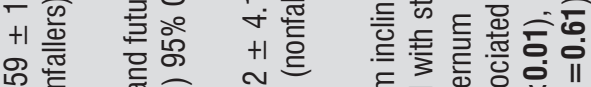

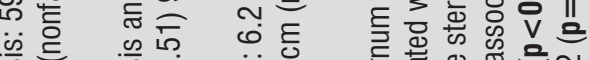

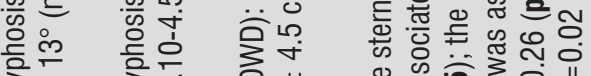

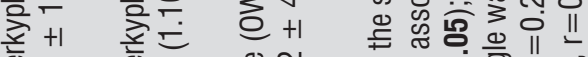

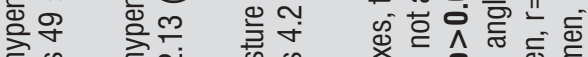

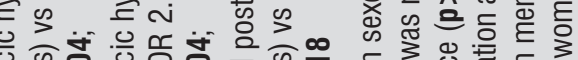

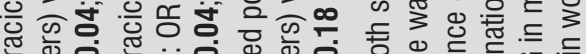

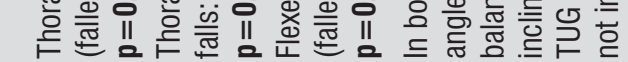

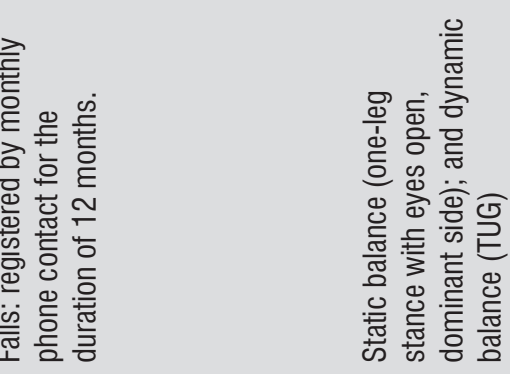

in

응

잉

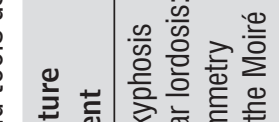

त ल

\section{(1)}

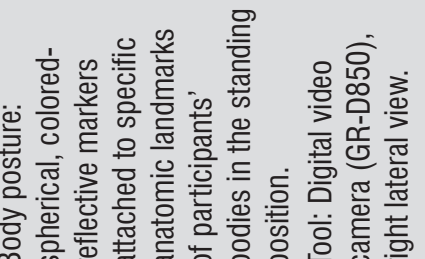

응 융 응

응 웅

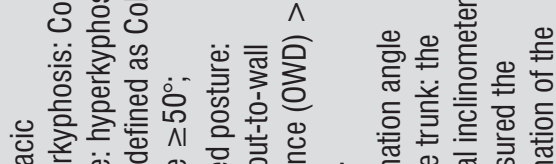

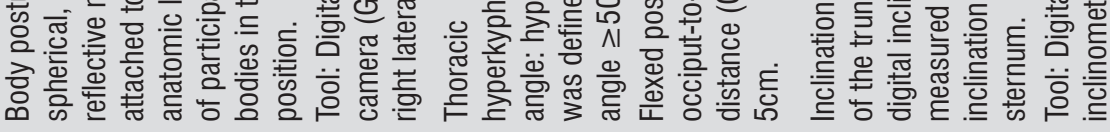

:

$+1$

通 क

ณ

这离

迹

言 총

잉 등

든 응ㅇ

के

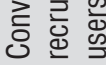

끌

్ㅡㅇ

त्ठ

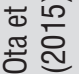

$\stackrel{\infty}{+}$

$+1$

으옹

的丞

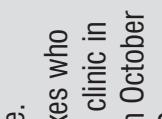

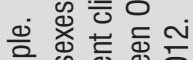

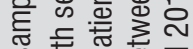

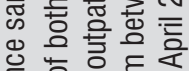

嵌

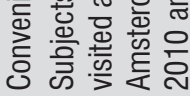

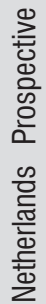

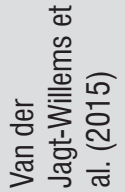

is 듕 앵

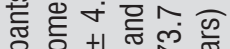

饶少的

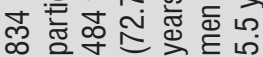

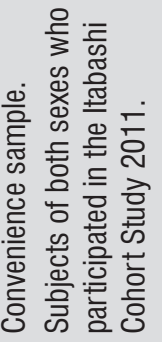

흥

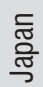

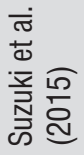




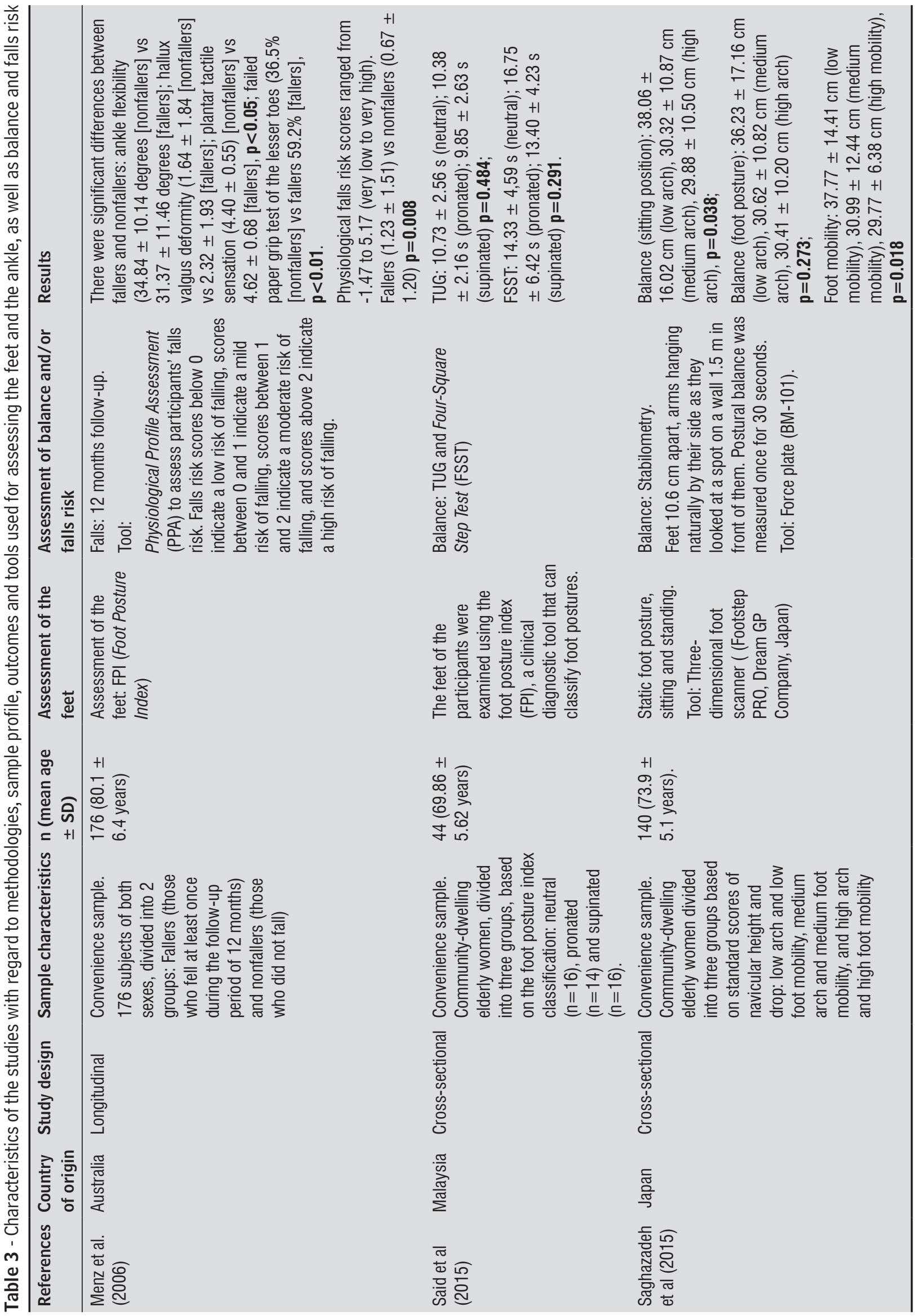


The methodological quality of the studies is shown in Table 4. All studies clearly described their objectives, assessment tools, statistics and outcomes. Only one study [31] failed to describe the eligibility and inclusion criteria of the participants (sample). Five studies [25, 26, 29, 33] did not describe the reliability of the tools used in the study, while two studies offered a questionable description of the tools' reliability [31, 36]. All studies but one [32] described their clinical implications. Finally, three studies did not mention limitations [22, 26, 33].

Table 4 - Methodological assessment results (STROBE)

\begin{tabular}{|c|c|c|c|c|c|c|c|c|c|c|c|c|c|c|c|}
\hline Author & 1 & 2 & 3 & 4 & 5 & 6 & 7 & 8 & 9 & 10 & 11 & 12 & 13 & 14 & 15 \\
\hline Menz et al, 2006 & + & + & + & 0 & NA & + & + & + & 0 & + & + & + & + & + & + \\
\hline Antonelli-Incalzi, 2007 & + & - & + & 0 & NA & $?$ & + & 0 & 0 & + & + & 0 & + & + & + \\
\hline Kado et al, 2007 & + & + & + & 0 & + & + & + & + & 0 & + & $?$ & + & + & + & + \\
\hline Said et al, 2008 & + & $?$ & + & + & NA & + & + & + & $?$ & + & + & + & + & + & + \\
\hline Yusi Kasukawa et al., 2010 & + & - & + & 0 & NA & + & + & + & 0 & + & + & + & + & + & + \\
\hline Regolin \& Carvalho, 2010 & + & + & + & 0 & + & + & + & 0 & 0 & + & + & + & + & + & + \\
\hline Abe et al, 2013 & + & + & + & 0 & NA & + & + & + & 0 & + & $?$ & + & + & + & + \\
\hline Eum et al.,2013 & + & - & + & 0 & NA & + & + & + & 0 & + & + & + & + & + & + \\
\hline Ishikawa et al., 2013 & + & + & + & 0 & NA & + & + & + & 0 & + & $?$ & - & + & + & 0 \\
\hline Imagama et al, 2013 & + & $?$ & + & 0 & NA & + & + & + & $?$ & + & + & + & + & + & + \\
\hline Miyazaki el al, 2013 & + & $?$ & + & 0 & NA & + & + & + & $?$ & + & $?$ & - & + & + & + \\
\hline Groot et al, 2014 & + & $?$ & + & 0 & NA & + & + & 0 & 0 & + & $?$ & - & + & + & 0 \\
\hline Ota et al, 2015 & + & + & + & 0 & NA & + & + & + & 0 & + & - & - & + & $?$ & + \\
\hline Van der Jagt-Willems et al., 2015 & + & + & + & 0 & NA & + & + & 0 & 0 & + & + & + & + & + & + \\
\hline Suzuki et al., 2015 & + & + & + & 0 & NA & + & + & 0 & 0 & + & + & + & + & + & 0 \\
\hline Saghazadeh, et al, 2015 & + & $?$ & + & 0 & NA & + & + & $?$ & + & + & + & - & + & + & + \\
\hline Drzał-Grabiec, et al, 2014 & + & 0 & 0 & 0 & NA & + & + & $?$ & $?$ & + & $?$ & - & + & + & + \\
\hline
\end{tabular}

Note: $(+)$ = positive rating; $(?)=$ questionable study design or methodology; $(-)=$ negative rating; $(0)=$ information unavailable; (NA) = not applicable

\section{Discussion}

Thus, this systematic review aimed to investigate whether postural changes increase fall risk and/or postural imbalance in healthy, community-dwelling older adults. In total, 17 articles were eligible and included for review. They used different tools to assess body posture, not only at the vertebral level, but also at the level of the ankles and the feet.

Postural deformities, such as thoracic hyperkyphosis, flexed posture, loss of lumbar lordosis, forward trunk inclination, and decreased plantar arch negatively affected postural balance and risk of falls in healthy older adults. Our findings are in line with those reported by Groot, Van der JagtWillems [18], in which postural control was affected in osteoporotic older adults with vertebral fractures, thoracic hyperkyphosis and flexed posture.
Most of the studies measured thoracic kyphosis [21 - 24, 26 - 31]. Thirty-six percent of older adults with thoracic hyperkyphosis had experienced falls and were 1.32 times more likely to report a fall in the past year than were those with normal kyphosis [28]. According to Kado [15], the relationship between thoracic hyperkyphosis and falls in women could be explained by age. In the study by Van der Jagt-Willems et al. [27], patients with hyperkyphosis were twice more likely to fall than their counterparts, regardless of sex. In contrast, Kasukawa et al. [21] and Ishikawa, Miyakoshi et al. [22] found no correlation between falls and increased thoracic hyperkyphosis.

Thoracic hyperkyphosis, flexed posture and forward trunk inclination are changes in the sagittal plane of the vertebral column that lead to a forward projection of the gravity line, negatively affecting 
postural balance $[37,38]$. This is confirmed by the findings of this review, in which poorer stabilometry results were associated with postural malalignment and falls [21, 22, 24, 29, 31]. Previous studies have also associated thoracic hyperkyphosis with loss of mobility, reduced quality of life and increased falls risk in osteoporotic older adults $[11,16,39,40]$.

A relevant finding of this systematic review is that balance and risk of falls in older adults is not only affected by thoracic deformities such as thoracic hyperkyphosis. Special attention should be given to the lumbar spine, because several studies found an association between changes in lumbar curvature and poorer balance-test performance (as measured by stabilometry) and increased incidence of falls in healthy older adults [21-24, 31, 32].

Loss of lumbar lordosis leads to pelvic retroversion and posterior shift of the gravity line [38]. In the study by Ishikawa et al. [10], loss of lumbar lordosis increased postural instability and propensity to fall in older adults with osteoporosis. Thus, both thoracic hyperkyphosis and loss of lumbar lordosis induce a displacement of the gravity line (GL) in the sagittal plane, reducing stability limits in all directions, as well as the magnitude of response and displacement speed, especially in the antero-posterior axis, fostering an increased postural balance in older adults [37].

Thus, the ankles and feet should also be taken into account when analyzing the influence of posture on balance and the risk of falls in healthy older adults. The feet play an important role in body stabilization, since it contributes to weight load distribution in the bipedal position and influences balance and balance control during gait $[34,41]$. Studies have associated foot characteristics with the risk of falls in older adults. Loss of ankle mobility and plantar tactile sensation, deformities and toe weakness were found to negatively affect balance, gait speed and functional mobility test performance $[7,41,42]$.

The maintenance of body balance depends on a complex, coordinate interaction of vestibular, somatosensory and visual systems, which hold the body's center of mass over the base of support [43]. This is why the use of multidimensional measures has been advocated for the assessment of balance and risk of falls in older adults. The Clinical Guidance Statement on Management of Falls [44] recommends the screening of different risk factors for falls and interventions, such as foot assessment and footwear correction, with level two evidence. It is important to highlight that other variables associated with postural changes may influence balance impairment and risk of falls in older adults, such as visual and proprioceptive muscle response [31], paravertebral muscle weakness [21 - 24], decreased spinal mobility [21] and low physical function [8].

Although postural alignment changes with ageing, stretching and strengthening exercise programs to paravertebral muscles may help to prevent or minimize these changes. In a twelve-month follow-up study, Pawlowsky et al. [45] found that older women receiving in-home physical therapy sessions twice a week for 12 months showed improved paravertebral strength and flexibility, and reduced thoracic kyphosis by $3^{\circ}$. Similar results were found in the study by Katzman et al. [46] with hyperkyphotic older women.

Despite the complexity of postural control and balance maintenance mechanisms in healthy older adults, this review shows that postural assessment in older adults should be part of the daily clinical routine of physical therapists, as a variable that still needs to be investigated as a risk factor for falls in healthy older adults. Moreover, exercise programs that contribute to increasing paravertebral muscle strength and flexibility should be included in the therapy prescribed by physical therapy professionals.

Some of the limitations of the studies included in this review were, first, the great variability of methods used to assess posture - ranging from more subjective (visual postural assessment) to more accurate technologies (SpinalMouse); second, the great variability of tools used to assess balance - from stabilometry to functional tests; third, some authors did not describe the reliability and reproducibility of the assessment tools; and, finally, the fact that some studies were cross-sectional and therefore did not assess the cause-effect relationship between postural changes, and/or impaired balance in communityliving older adults.

\section{Conclusion}

This review shows that there is evidence that postural changes such as thoracic hyperkyphosis, loss of lumbar lordosis and decreased plantar arch seem to contribute to the increased postural instability and consequently an increased risk of falls in communityliving older adults. However, since there is no 
consensus on the best method to assess balance in older adults, further studies should be conducted to elucidate this issue. Moreover, longitudinal studies need to be conducted to investigate the causeeffect relationship between age-related postural changes, and balance and falls in community-living older adults.

\section{References}

1. Rubenstein LZ. Falls in older people: epidemiology, risk factors and strategies for prevention. Age Ageing. 2006;35(Suppl 2):ii37-ii41.

2. Cruz DT, Ribeiro LC, Vieira MT, Teixeira MTB, Bastos RR, Leite ICG. Prevalência de quedas e fatores associados em idosos. Rev Saude Publica. 2012;46(1):138-46.

3. Siqueira F, Facchini L, Piccini R, Tomasi E, Thumé E, Silveira D, et al. Prevalência de quedas em idosos e fatores associados. Rev Saude Publica. 2007;41(5):749-56.

4. Perracini MR, Ramos LR. Fatores associados a quedas em uma coorte de idosos residentes na comunidade. Rev Saude Publica. 2002;36(6):709-16.

5. Moreland J, Richardson J, Chan D, O'Neill J, Bellissimo A, Grum R, et al. Evidence-based guidelines for the secondary prevention of falls in older adults. Gerontology. 2003;49(2):93-116.

6. Ueno M, Kawai S, Mino T, Kamoshita H. Systematic review of fall-related factors among the housedwelling elderly in Japan. Nihon Ronen Igakkai Zasshi. 2006;43(1):92-101.

7. Tinetti ME, Speechley M, Ginter SF. Risk factors for falls among elderly persons living in the community. N Engl J Med. 1988;319(26):1701-7.

8. Abe Y, Aoyagi K, Tsurumoto T, Chen CY, Kanagae M, Mizukami S, et al. Association of spinal inclination with physical performance measures among communitydwelling Japanese women aged 40 years and older. Geriatr Gerontol Int. 2013;13(4):881-6.

9. Karakasidou P, Skordilis EK, Dontas I, Lyritis GP. Postural profile and falls of osteoporotic women. JBack Musculoskelet Rehabil. 2012;25(1):55-66.
10. Ishikawa Y, Miyakoshi N, Kasukawa Y, Hongo M, Shimada Y. Spinal curvature and postural balance in patients with osteoporosis. Osteoporos Int. 2009;20(12):2049-53.

11. Sinaki M, Brey RH, Hughes CA, Larson DR, Kaufman KR. Balance disorder and increased risk of falls in osteoporosis and kyphosis: significance of kyphotic posture and muscle strength. Osteoporos Int. 200516(8):1004-10.

12. Balzini L, Vannucchi L, Benvenuti F, Benucci $M$, Monni M, Cappozzo A, et al. Clinical Characteristics of Flexed Posture in Elderly Women. J Am Geriatr Soc. 2003;51(10):1419-26.

13. Lindsey C. Comprometimento da Postura. In: Guccione AA, Wong AR, Avers D, editors. Fisioterapia Geriátrica. 3rd ed. Rio de Janeiro: Guanabara Koogan; 2013. p. 263-84.

14. Drzał-Grabiec J, Snela S, Rykała J, Podgórska J, Banaś A. Changes in the body posture of women occurring with age. BMC Geriatr. 2013;13:108.

15. Kado DM. The rehabilitation of hyperkyphotic posture in the elderly. Eur J Phys Rehabil Med. 2009;45(4):583-93.

16. Katzman WB, Wanek L, Shepherd JA, Sellmeyer DE. Age-related hyperkyphosis: its causes, consequences, and management. J Orthop Sports Phys Ther. 2010;40(6):352-60.

17. Hsu WL, Chen CY, Tsauo JY, Yang RS. Balance control in elderly people with osteoporosis. J Formos Med Assoc. 2014;113(6):334-9.

18. Groot $\mathrm{MH}$, van der Jagt-Willems HC, van Campen JP, Lems WF, Lamoth CJ. Testing postural control among various osteoporotic patient groups: a literature review. Geriatr Gerontol Int. 2012;12(4):573-85.

19. Malta M, Cardoso LO, Bastos FI, Magnanini MMF, Silva CMFP. Iniciativa STROBE: subsídios para a comunicação de estudos observacionais. Rev Saude Publica. 2010;44(3):559-65.

20. Moher D, Liberati A, Tetzlaff J, Altman DG; PRISMA Group. Preferred reporting items for systematic reviews and meta-analyses: the PRISMA statement. PLoS Med. 2009;6(7):e1000097. 
21. Kasukawa Y, Miyakoshi N, Hongo M, Ishikawa Y, Noguchi H, Kamo K, et al. Relationships between falls, spinal curvature, spinal mobility and back extensor strength in elderly people. J Bone Miner Metab. 2010;28(1):82-7.

22. Ishikawa $\mathrm{Y}$, Miyakoshi N, Kasukawa $\mathrm{Y}$, Hongo M, Shimada Y. Spinal sagittal contour affecting falls: cutoff value of the lumbar spine for falls. Gait Posture. 2013;38(2):260-3.

23. Miyazaki J, Murata S, Horie J, Uematsu A, Hortobágyi T, Suzuki S. Lumbar lordosis angle (LLA) and leg strength predict walking ability in elderly males. Arch Gerontol Geriatr. 2013;56(1):141-7.

24. Imagama S, Ito Z, Wakao N, Seki T, Hirano K, Muramoto A, et al. Influence of spinal sagittal alignment, body balance, muscle strength, and physical ability on falling of middle-aged and elderly males. Eur Spine J. 2013;22(6):1346-53.

25. Antonelli-Incalzi R, Pedone C, Cesari M, Di Iorio A, Bandinelli S, Ferrucci L. Relationship between the occiput-wall distance and physical performance in the elderly: a cross sectional study. Aging Clin Exp Res. 2007;19(3):207-12.

26. Groot MH, van der Jagt-Willems HC, van Campen JP, Lems WF, Beijnen JH, Lamoth CJ. A flexed posture in elderly patients is associated with impairments in postural control during walking. Gait Posture. 2014;39(2):767-72.

27. Van der Jagt-Willems HC, Groot MH, van Campen JPCM, Lamoth CJC, Lems WF. Associations between vertebral fractures, increased thoracic kyphosis, a flexed posture and falls in older adults: a prospective cohort study. BMC Geriatr. 2015;15:34.

28. Kado DM, Huang MH, Nguyen CB, Barrett-Connor E, Greendale GA. Hyperkyphotic posture and risk of injurious falls in older persons: the Rancho Bernardo Study. J Gerontol A Biol Sci Med Sci. 2007;62(6):652-7.

29. Regolin F, Carvalho GA. Relationship between thoracic kyphosis, bone mineral density, and postural control in elderly women. Rev Bras Fisioter. 2010;14(6):464-9.

30. Eum R, Leveille SG, Kiely DK, Kiel DP, Samelson EJ, Bean JF. Is kyphosis related to mobility, balance, and disability? Am J Phys Med Rehabil. 2013;92(11):980-9.
31. Drzał-Grabiec J, Rachwał M, Podgórska-Bednarz J, Rykała J, Snela S, Truszczyńska A, et al. The effect of spinal curvature on the photogrammetric assessment on static balance in elderly women. BMC Musculoskelet Disord. 2014;15:186.

32. Ota S, Goto H, Noda Y, Fujita R, Matsui Y. Relationship between standing postural alignments and physical function among elderly women using day service centers in Japan. J Back Musculoskelet Rehabil. 2015;28(1):111-7.

33. Suzuki Y, Kawai H, Kojima M, Shiba Y, Yoshida H, Hirano $\mathrm{H}$, et al. Construct validity of posture as a measure of physical function in elderly individuals: Use of a digitalized inclinometer to assess trunk inclination. Geriatr Gerontol Int. 2016;16(9):1068-73.

34. Menz HB, Morris ME, Lord SR. Foot and ankle risk factors for falls in older people: A prospective study. J Gerontol A Biol Sci Med Sci. 2006;61(8):866-70.

35. Said AM, Manaf H, Bukry SA, Justine M. Mobility and Balance and Their Correlation with Physiological Factors in Elderly with Different Foot Postures. Biomed Res Int. 2015;2015:385269.

36. Saghazadeh M, Tsunoda K, Soma Y, Okura T. Static foot posture and mobility associated with postural sway in elderly women using a three-dimensional foot scanner. J Am Podiatr Med Assoc. 2015. [Epub ahead of print]

37. Schwab F, Lafage V, Boyce R, Skalli W, Farcy JP. Gravity line analysis in adult volunteers: age-related correlation with spinal parameters, pelvic parameters, and foot position. Spine (Phila Pa 1976). 2006;31(25):E959-67.

38. Lafage V, Schwab F, Skalli W, Hawkinson N, Gagey PM, Ondra S, et al. Standing balance and sagittal plane spinal deformity: analysis of spinopelvic and gravity line parameters. Spine (Phila Pa 1976). 2008;33(14):1572-8.

39. Katzman WB, Vittinghoff E, Ensrud K, Black DM, Kado DM. Increasing kyphosis predicts worsening mobility in older community-dwelling women: a prospective cohort study. J Am Geriatr Soc. 2011;59(1):96-100.

40. MacIntyre NJ, Lorbergs AL, Adachi JD. Inclinometerbased measures of standing posture in older adults with low bone mass are reliable and associated with self-reported, but not performance-based, physical function. Osteoporos Int. 2014;25(2):721-8. 
41. Menz HB, Morris ME, Lord SR. Foot and ankle characteristics associated with impaired balance and functional ability in older people. J Gerontol A Biol Sci Med Sci. 2005;60(12):1546-52.

42. Menz HB, Lord SR. The contribution of foot problems to mobility impairment and falls in community-dwelling older people. J Am Geriatr Soc. 2001;49(12):1651-6.

43. Perracini MR, Gazzola JM. Balance em Idosos. In: Perracini MR, Fló CM, editors. Funcionalidade e Envelhecimento. Rio de Janeiro: Guanabara Koogan; 2009. p. 115-51.

44. Avin KG, Hanke TA, Kirk-Sanchez N, McDonough CM, Shubert TE, Hardage J, et al. Management of falls in community-dwelling older adults: clinical guidance statement from the Academy of Geriatric Physical Therapy of the American Physical Therapy Association. Phys Ther. 2015;95(6):815-34.
45. Pawlowsky SB, Hamel KA, Katzman WB. Stability of kyphosis, strength, and physical performance gains 1 year after a group exercise program in communitydwelling hyperkyphotic older women. Arch Phys Med Rehabil. 2009;90(2):358-61.

46. Katzman WB, Sellmeyer DE, Stewart AL, Wanek L, Hamel KA. Changes in flexed posture, musculoskeletal impairments, and physical performance after group exercise in communitydwelling older women. Arch Phys Med Rehabil. 2007;88(2):192-9.

Received in 06/16/2016

Recebido em 16/06/2016

Approved in 09/18/2017

Aprovado em 18/09/2017 